\title{
INTEGRATED APPROACH FOR THE MANAGEMENT OF WATER HYACINTH (Eichhornia Crassipes)
}

\section{SINGH RANU*, AGARWAL PRAGYA AND DHAGAT MONIKA}

Department of Botany, Mata Gujri Mahila Mahavidyalaya, Jabalpur, MP, India.

*Corresponding Author: Email- ranusing4@gmail.com

\begin{abstract}
Water hyacinth [Eichhornia crassipes (Mart.) Solms] is a noxious aquatic weed. In India,it has infested more than 200,000 ha of water surface. During the course of present investigation it was proposed to make an extensive, planned and systematic survey of fungal pathogens that destroy the water hyacinth from the ponds of M.P. The study was undertaken to evaluate the compatibility of two or more fungi for integrated management of water hyacinth. Results clearly indicate that except Alternaria eichhorniae all the pathogens are compatible to each other. In vivo the lesion diameters were greater on water hyacinth leaves when combination of pathogens were used than individual pathogens. The Alternaria alternata, Curvularia lunata and Fusarium pallidoroseum combination resulted in maximum disease development followed by $A$. alternata with $C$. lunata, A. alternata with F. pallidoroseum and C. lunata with F. pallidoroseum. Thus, it can be concluded that better management of the weed can be achieved by using combination of pathogens.
\end{abstract}

Key words- Integrated management, water hyacinth, compatability.

Citation: Singh Ranu, Agarwal Pragya and Dhagat Monika (2012) Integrated Approach for The Management of Water Hyacinth (Eichhornia crassipes). International Journal of Microbiology Research, ISSN: 0975-5276 \& E-ISSN:0975-9174, Volume 4, Issue 4, pp.-215-216.

Copyright: Copyright@2012 Singh Ranu, Agarwal Pragya and Dhagat Monika. This is an open-access article distributed under the terms of the Creative Commons Attribution License, which permits unrestricted use, distribution, and reproduction in any medium, provided the original author and source are credited.

\section{Introduction}

Water hyacinth, Eichhornia crassipes (Mart.) Solms (Pontederiaceae), continues to pose serious economic, social and environmental problem in India and many other countries in the tropics and subtropics [8]. In recent years, attention has centered on biological control, which could provide a cost-effective environmentally safe, solution to the water hyacinth problem $[1,2,4,5,7]$. Most emphasis has been given to fungal pathogens as biocontrol agents [11-13]. Integrated management of weeds is a holistic approach aimed at maximizing pest impact while simultaneously maintaining the integrity of the ecosystem. It is also important to recognize the strengths and limitations of each control techniques and to integrate the appropriate technique in time and space to achieve the best result. In general chemical and physical control can be used to reduce the weed in critical areas while biological control is being instigated. Once biological control has reduced the population of the weed, additional control should not be re- quired in most areas. Combinations of treatment can be more effective for controlling water hyacinth than individual treatments. Fungal mycoherbicides prepared from Cercospora rodmanii has been considerably enhanced when applied to water hyacinth in presence of Neochetina weevils [9].

\section{Material and method Integration of two or more fungi}

A study was undertaken to evaluate the compatibility of combination of two or more fungi in integrated management of water hyacinth. Pure culture of the fungi was grown separately on Richards's media [3]. $5 \mathrm{~mm}$ discs of each test fungus were cut from the stock culture plates with the help of sterilized cork borer and transferred on plates with growth media. The disc were placed about $2 \mathrm{~cm}$. apart to give equal opportunity to all the test pathogens. The different 5 fungus tested were Alternaria alternata, Alternaria eichhorniae, Aspergillus flavus, Curvularia lunata, 
Fusarium pallidoroseum. A separate set containing only single pathogen in each plate was kept as control. The plates were incubated at $25^{\circ} \mathrm{C}$ for 21 days. All the experiments were done in triplicates. After 21 days, the spores were washed from the above plates and sprayed on water hyacinth plants. Control plants were inoculated with single pathogen while control over control was sprayed with sterilized distilled water.

\section{Result}

Many fungal pathogens were isolated and purified from various disease sample of water hyacinth and their biocontrol potential was evaluated. Out of these fungi 4 were pathogenic. The severe infection caused by Alternaria alternata (41\%), than Curvularia lunata (30\%), Fusarium pallidoroseum (26.7\%) Alternaria eichhorniae (15.6\%) (Table- I).

Result presented in table - II clearly indicates that except Alternaria eichhorniae all the pathogens are compatible to each other. Radial growth was equally good and comparable to control plates. The sporulation of all the fungi tested for compatibility was excellent and comparable to the control plates. In vivo the lesion diameters were greater on water hyacinth leaves when combination of pathogens were used than when individual pathogens (table II). The Alternaria alternata, Curvularia lunata and Fusarium pallidoroseum combination resulted in maximum disease development followed by Alternaria alternata and Curvularia lunata combination, Alternaria alternata and Fusarium pallidoroseum combination and Curvularia lunata and Fusarium pallidoroseum combination gave similar results. Similar observations have been made by several other workers $[6,10,14]$.

Table 1- Damage caused by Pathogenic fungi on Water hyacinth

\begin{tabular}{|llll|}
\hline Pathogenic fungi & \multicolumn{3}{c}{ \% Damage } \\
\hline Alternaria alternata & 9.7 & 10 days & 15 days \\
Curvularia lunata & 7.0 & 26.7 & 41.0 \\
Fusarium pallidoroseum & 5.3 & 15.0 & 30.0 \\
Alternaria eichhorniae & 2.3 & 11.3 & 26.7 \\
\hline
\end{tabular}

Table 2- Combined effect of various pathogens for integrated management of water hyacinth

\begin{tabular}{llll} 
& \multicolumn{4}{c}{ Disease Percentage } \\
Pathogens & 5 days & 10 days & 15 days \\
\hline Alternaria alternata+Curvularia lunata & 11.3 & 35.7 & 82.0 \\
Alternaria alternata + Fusarium palli- & 9.7 & 31.0 & 56.0 \\
doroseum & & & \\
Curvularia lunata + Fusarium pallidoroseum & 10.0 & 34.0 & 52.7 \\
$\begin{array}{lll}\text { Alternaria alternata + Curvularia lunata+ } \\
\text { Fusarium pallidoroseum }\end{array}$ & 16.3 & 42.0 & 85.7 \\
\hline
\end{tabular}

Thus it can be concluded that better control of the weed can be achieved using combination of pathogens. The studies confirmed and reinforced the view that the pathogens especially Alternaria alternata can effective partners in integrated control of water hyacinth.

The combined treatments wear found to be causing quicker disease incidence than individual treatments. The application of the three fungi $A$. alternata, $C$. lunata and $F$. pollidoroseum caused maximum disease development. Alternaria alternata surely have great potential specially in combination with each other to control water hyacinth in an ecofriendly manner.

\section{Acknowledgements}

At first we would like to give heartiest thanks to Principal of Mata Gujri Mahila Mahavidyalaya Jabalpur, Dr. (Mrs.) Vineeta Kaur Saluja, without whose permission this work would have been impossible. We would like to give heartiest thanks to MPCST for their financial assistance.

\section{References}

[1] Aneja K.R. (1996) SES and PSCST.

[2] Aneja K.R. and Singh K. (1989) Crop pest management, 35, 354-356.

[3] Agarwal G.P. and Hasija S.K. (1986) A laboratory guide mycology, microbiology and plant pathology, 155.

[4] Center T.D. (1994) In: Pest management in the subtropics : Biological control - A Florida perspectives.

[5] Charudattan R., Linda S.B., Kluepfel M. and Osman Y.A. (1985) Phytopathology 75, 1263-1269.

[6] Charudattan R. (1984) Int. Conf. on waterhyacinth. United Nations Env. Prog. Box 30552 Nairobi, Kenya.

[7] Charudattan R. and Dinoor A. (2000) Biological control of weeds using plant pathogens: accomplishments and limitation Crop. Protection.

[8] Gopal B. and K.P. Sharma (1981). Water hyacinth (Eichhornia crassipes). Most troublesome weed of the world.

[9] Moran Pattrick J. (2000) http: // www.Springerlint.Com/ Content/r723246774 72jj54/.

[10]Pandey A.K. (1998) Integrated approach for the management of Parthenium hysterophorus L.D. Sc. Thesis R.D. University, Jabalpur, MP, India, 157.

[11]Shabana Y.M., Charudattan R., Elwakil M.A. (1995a) Biological Control, 32, 78-89.

[12]Shabana Y.M., Charudattan R., Elwakil M.A. (1995b) Biological Control, 5,136-144.

[13]Vincent A.C. (2001) Cercospora piaropi and Myrothecium roridum as potential bioherbicides to control waterhyacinth, Eichhornia crassipes. Thesis, University of Florida, USA.

[14]Yasser M., Shabana and Mohamed Z.A. (2005) Biocontrol Science and Technology, 15(7), 659-669. 